\title{
Soil denitrifier community size changes with land use change to perennial bioenergy cropping systems
}

\author{
Karen A. Thompson ${ }^{1}$, Bill Deen ${ }^{2}$, and Kari E. Dunfield ${ }^{1}$ \\ ${ }^{1}$ School of Environmental Sciences, University of Guelph, 50 Stone Road East, \\ Guelph, Ontario, N1G 2W1, Canada \\ ${ }^{2}$ Department of Plant Agriculture, University of Guelph, 50 Stone Road East, \\ Guelph, Ontario, N1G 2W1, Canada \\ Correspondence to: Kari E. Dunfield (dunfield@uoguelph.ca)
}

Received: 26 April 2016 - Published in SOIL Discuss.: 12 May 2016

Revised: 11 September 2016 - Accepted: 2 October 2016 - Published: 19 October 2016

\begin{abstract}
Dedicated biomass crops are required for future bioenergy production. However, the effects of largescale land use change (LUC) from traditional annual crops, such as corn-soybean rotations to the perennial grasses (PGs) switchgrass and miscanthus, on soil microbial community functioning is largely unknown. Specifically, ecologically significant denitrifying communities, which regulate $\mathrm{N}_{2} \mathrm{O}$ production and consumption in soils, may respond differently to LUC due to differences in carbon $(\mathrm{C})$ and nitrogen $(\mathrm{N})$ inputs between crop types and management systems. Our objective was to quantify bacterial denitrifying gene abundances as influenced by corn-soybean crop production compared to PG biomass production. A field trial was established in 2008 at the Elora Research Station in Ontario, Canada $(n=30)$, with miscanthus and switchgrass grown alongside corn-soybean rotations at different $\mathrm{N}$ rates $\left(0\right.$ and $\left.160 \mathrm{~kg} \mathrm{Nha}^{-1}\right)$ and biomass harvest dates within PG plots. Soil was collected on four dates from 2011 to 2012 and quantitative PCR was used to enumerate the total bacterial community (16S rRNA) and communities of bacterial denitrifiers by targeting nitrite reductase (nirS) and $\mathrm{N}_{2} \mathrm{O}$ reductase (nosZ) genes. Miscanthus produced significantly larger yields and supported larger nos $\mathrm{Z}$ denitrifying communities than corn-soybean rotations regardless of management, indicating large-scale LUC from corn-soybean to miscanthus may be suitable in variable Ontario climatic conditions and under varied management, while potentially mitigating soil $\mathrm{N}_{2} \mathrm{O}$ emissions. Harvesting switchgrass in the spring decreased yields in $\mathrm{N}$-fertilized plots, but did not affect gene abundances. Standing miscanthus overwinter resulted in higher $16 \mathrm{~S}$ rRNA and nirS gene copies than in fall-harvested crops. However, the size of the total (16S rRNA) and denitrifying bacterial communities changed differently over time and in response to LUC, indicating varying controls on these communities.
\end{abstract}

\section{Introduction}

Future energy needs require dedicated biomass crop production for bioethanol and combustion-based electricity generation. Corn (Zea mays L.)-soybean (Glycine max L.) rotations currently dominate the landscape across Ontario and the northern US Corn Belt (Gaudin et al., 2015), and corn grain is currently the primary feedstock for bioethanol production in Canada (Jayasundara et al., 2014). The $\mathrm{C}_{4}$ perennial grasses (PGs) switchgrass (Panicum virgatum L.) and miscanthus (Miscanthus spp.) have been proposed as alter- nate feedstock crops to corn for biomass-based bioenergy production due to their large biomass yields, reduced nitrogen $(\mathrm{N})$ and water requirements, decreased nutrient leaching, and potential for increased soil carbon (C) storage (BlancoCanqui and Lal, 2009; Foster et al., 2013). Large-scale production of $\mathrm{C}_{4}$ PGs in Ontario and the northern Corn Belt would require land use change (LUC) from existing cornsoybean rotations to PG biomass cropping systems (Deen et al., 2011; Kludze et al., 2013; Liang et al., 2012; Sanscartier et al., 2014). 
Few studies have assessed how this LUC may influence soil microbial community functioning. In particular, soil denitrifying communities represent an ideal subset of the soil microbial community to target to assess changes in ecosystem functioning due to agricultural management and LUC. Denitrifying bacteria represent approximately $5 \%$ of the total soil microbial biomass (Braker and Conrad, 2011) and have been identified in over 60 genera (Philippot, 2006), encompassing a wide range of phylogenetic and functional diversity. Multiple studies have linked changes in denitrifier communities with plant types or development stage (Bremer et al., 2007; Hai et al., 2009; Petersen et al., 2012), N fertilization (Hallin et al., 2009; Yin et al., 2014), organic or conventional crop management (Reeve et al., 2010), perennial vs. annual crop land use (Bissett et al., 2011), and C and N inputs (Bastian et al., 2009). These studies suggest that LUC from cornsoybean rotations to $\mathrm{PG}$ species may influence the soil bacterial communities which drive soil $\mathrm{N}_{2} \mathrm{O}$ production and consumption.

$\mathrm{N}_{2} \mathrm{O}$ is a potent greenhouse gas with a global warming potential $296 \times$ that of $\mathrm{CO}_{2}$ (IPCC, 2007). However, measuring $\mathrm{N}_{2} \mathrm{O}$ directly in the field is often difficult with chamber methods in cropping systems that produce large aboveground biomass. Additionally, including multiple field treatments (e.g. as in a randomized complete block design) makes micrometeorological methods of $\mathrm{N}_{2} \mathrm{O}$ flux impossible to obtain. Instead, relative abundances of denitrifier genes can be used to assess a soil's potential to produce (e.g. nirS or nirK) and consume (e.g. $\operatorname{nos} Z$ ) $\mathrm{N}_{2} \mathrm{O}$ via denitrification, representing a qualitative proxy of relative $\mathrm{N}_{2} \mathrm{O}$ emission potential of a soil (Butterbach-Bahl et al., 2013; Hallin et al., 2009; Morales et al., 2010; Petersen et al., 2012; Philippot, 2002). Denitrifier community size has been correlated with denitrification process rates (Hallin et al., 2009; Wu et al., 2012) and denitrification potential (Attard et al., 2011; Cuhel et al., 2010; Enwall et al., 2010). Potential denitrifying activity and denitrifying community size have also been shown to be correlated with each other in some studies (Hallin et al., 2009; Morales et al., 2010; Szukics et al., 2010; Throbäck et al., 2007), suggesting community size may indicate potential differences in soil $\mathrm{N}$ processes after LUC. Particularly, the nosZ-bearing community may act as a $\mathrm{N}_{2} \mathrm{O}$ sink and counter high $\mathrm{N}_{2} \mathrm{O}$ production rates (Braker and Conrad, 2011; Philippot et al., 2011), therefore influencing $\mathrm{N}_{2} \mathrm{O}$ emissions (Cuhel et al., 2010; Morales et al., 2010; Philippot et al., 2011).

Denitrification nirS and nos $Z$ gene targets represent the two most important steps in the denitrification pathway that produce gaseous by-products, and account for a large proportion of functional $\mathrm{N}$ genes in some studies (Stone et al., 2015). The first step in denitrification that produces a gaseous $\mathrm{N}$ product is the reduction of nitrite $\left(\mathrm{NO}_{2}^{-}\right)$to nitric oxide (NO), catalyzed by nitrite reductases either encoded by the cytochrome $\mathrm{cd}_{1}$ ( nirS) or copper-containing (nirK) genes, which are equivalent but have not been detected within the same species (Zumft, 1997). We chose to quantify nirS be- cause three-quarters of cultured denitrifiers possess the nirS gene (Zumft, 1997) and some molecular reports indicate nirS may dominate in abundance over nirK in some natural environments (Deslippe et al., 2014; Nogales et al., 2002), indicating it may be a better-suited target for relative characterization of potential nitrite-reducing communities than nirK. Additionally, nirK has been recently identified in autotrophic ammonia-oxidizing species (Cantera and Stein, 2007; Casciotti and Ward, 2001), calling into question its utility in specifically targeting denitrifying communities. The nos $Z$ target codes for nitrous oxide reductase, which catalyzes the reduction of $\mathrm{N}_{2} \mathrm{O}$ to $\mathrm{N}_{2}$ in the denitrification pathway, indicating nosZ-bearing communities help to complete the $\mathrm{N}$ cycle and determine the $\mathrm{N}_{2} \mathrm{O}: \mathrm{N}_{2}$ balance. $16 \mathrm{~S}$ rRNA was chosen as a molecular target for the total bacterial community size; although $16 \mathrm{~S}$ rRNA gene copies vary from 1 to 15 copies per genome, its use has continued to be the "gold standard" for microbial ecology (Case et al., 2007; Vos et al., 2012). Although an alternate target, such as $\operatorname{rpoB}$, which is a single copy gene would be valuable if assessing phylogenetic diversity, there are no universal primers for it (Adékambi et al., 2009) as rрoB is not conserved enough to be of use as a universal marker and only a subset of the microbial community can be targeted (Vos et al., 2012). Many studies have used 16S rRNA gene copy numbers as a proxy for the total bacterial community size, and some have found that the total estimated numbers of proteobacteria species was not significantly different if using $r p o B$ or $16 \mathrm{~S}$ rRNA markers (Vos et al., 2012). As this study has not assessed phylogenetic relationships of the microbial communities, $16 \mathrm{~S}$ rRNA is an appropriate target for the relative comparison of the overall bacterial community size between environmental treatments/variables.

LUC resulting from displacement of corn-soybean rotations by PG production may alter soil microhabitats and therefore soil microbial N-cycling due both to extensive root and rhizome biomass and to large leaf litter inputs to soils in perennial vs. annual systems (Dohleman et al., 2012). Within studies targeting soil microbial communities in biomass cropping systems to date (Hedenec et al., 2014; Liang et al., 2012; Mao et al., 2013, 2011; Orr et al., 2015), the effects of various management practices (e.g. $\mathrm{N}$ fertilization and harvest) on soil microbial community functioning have not been an area of focus. The effect this type of LUC may have on soil microbial communities may depend on PG management practices in these systems.

Currently, there is no consensus regarding optimal $\mathrm{N}$ fertilization practices for increased yields in PG production as yield responses can be highly variable depending on environmental conditions and crop species (Deen et al., 2011). Depending on downstream use, miscanthus can be harvested in the fall pre-frost, harvested post-frost kill, or left to overwinter as standing biomass for harvest in the spring. Switchgrass is commonly harvested in the fall, and is often windrowed (cut, swathed, and left on soil) over winter due to produc- 
ers' limitations in collecting and storing harvested biomass in winter (REAP, 2008; Sokhansanj et al., 2009). Differences in $\mathrm{N}$ fertilizer requirements and harvest regimes may alter $\mathrm{C}$ and $\mathrm{N}$ inputs (Attard et al., 2011) and may influence LUC impacts on soil denitrifier community sizes.

Our objective was to compare the effects of LUC from corn-soybean to PG biomass production on the relative abundances of total (16S rRNA gene target) and denitrifier (nirS and nos $Z$ gene targets) soil bacterial communities 3-4 years after PG planting. Soil was collected on four dates from 2011 to 2012 from a field trial established in Ontario in 2008. This study is unique in that it consists of two PG biomass crops produced in parallel with the existing common land use of corn-soybean rotation within the same field trial site. It also includes unfertilized and fertilized plots in both annual and perennial systems, and varied harvest practices within PG plots. We hypothesized that soils from PG plots would support larger total bacterial and denitrifier communities than soils from corn-soybean plots due to increased shoot residue return and root inputs to soils in PG systems, as well as that soils from PG plots with biomass harvested in the spring would support larger total bacterial and denitrifier communities than supported by soils from PGs harvested in the fall due to increased root inputs and leaf loss to soil over winter.

\section{Materials and methods}

\subsection{Site description and experimental design}

A field trial was established in 2008 at the University of Guelph Research Station in Elora, ON $\left(43^{\circ} 38^{\prime} 46.73^{\prime \prime} \mathrm{N}\right.$, $\left.80^{\circ} 24^{\prime} 6.66^{\prime \prime} \mathrm{W}\right)$. The field site was cultivated on 16 May and 6 June 2008. Switchgrass (Panicum virgatum L. "Shelter") was planted on 6 June 2008. Miscanthus (M. sinensis $\times$ M. sacchariflorus 'Nagara', M116) was planted on 12 June 2008, and soybean (Glycine max L.) was planted on 24 June 2008 and annually rotated with corn (Zea mays L.). Corn was planted on 5 May 2010, soy was planted on 3 June 2011, and corn was re-planted on 18 May 2012, with annual light cultivation to prepare seedbeds for planting. In 2007, prior to trial establishment, the experimental area was planted to barley (Hordeum vulgare L.). The soil type is a London silt loam (Gray Brown Luvisol).

The field trial was a split-split-strip plot design with three replicates. The main plot factor was PG crop or annual rotation (miscanthus, switchgrass, and corn-soybean). Main treatment plots measured $6.2 \mathrm{~m} \times 26.0 \mathrm{~m}$. Nitrogen fertilizer $\left(0\right.$ or $\left.160 \mathrm{~kg} \mathrm{Nha}^{-1}\right)$ was applied in strips randomly within replicates. $160 \mathrm{~kg} \mathrm{Nha}^{-1}$ subplots received hand-broadcast urea fertilizer (46-0-0; N-P-K) in May 2011 or hand-broadcast ammonium nitrate fertilizer (34-0-0; N-P$\mathrm{K}$ ) in May 2012, after soil sampling procedures described below. Main treatments were split into two harvest timings (fall or spring) within the PG fertilizer strips only. Miscanthus plots were either harvested in the late fall season after post-frost kill or left standing to overwinter until spring harvest. Switchgrass plots were harvested in the fall or cut and assembled into windrows in the field for biomass removal in the spring. Spring harvest of PGs occurred before $\mathrm{N}$ fertilizer was applied. Harvest methods of PG yields (dry harvested biomass (tonnes) $\mathrm{ha}^{-1}$ ) are described in Deen et al. (2011). Figure 1 illustrates the seasonal and annual variation in daily average air temperature $\left({ }^{\circ} \mathrm{C}\right)$ and daily precipitation $(\mathrm{mm})$ measured at the Elora Research Station.

\subsection{Soil sampling and analysis}

Baseline bulk density and carbon measurements were measured for each main plot on 23 October 2010. For bulk density, two soil cores per plot were collected at $0-5 \mathrm{~cm}$ depth using $2.5 \mathrm{~cm}$ diameter cylindrical aluminum cores. Cores were weighed before and after drying for $24 \mathrm{~h}$ at $105^{\circ} \mathrm{C}$ (Maynard and Curran, 2007). For soil carbon analysis, 10 soil cores per plot were collected from both $0-15$ and $15-30 \mathrm{~cm}$ depths using a $5 \mathrm{~cm}$ diameter soil corer on a Z-shaped transect, and then composited per treatment plot for each depth. Total soil carbon and inorganic carbon were analyzed with a Leco ${ }^{\circledR}$ Carbon Determinator CR-12 (model no. 781-700, Leco Instruments Ltd.) following the dry combustion technique (Périé and Ouimet, 2008) on approximately $0.300 \mathrm{~g}$ of dried, ground, and homogenized soil (Table 1).

For molecular analyses, soil was sampled on four dates (9 May 2011, 30 October 2011, 2 May 2012, and 20 October 2012). October sampling dates occurred before fall harvest of PG crops, while May sampling dates occurred before $\mathrm{N}$ fertilizer application and after spring PG biomass removal (Fig. 1). Ten soil cores per plot were sampled aseptically to $15 \mathrm{~cm}$ depth using a $5 \mathrm{~cm}$ diameter soil corer on a Z-shaped transect, composited and kept on ice until transport back to the laboratory. The transect shape was chosen to encompass plot heterogeneity; at a pre-trial study date, initial analysis indicated gene abundances were not significantly different between bulk or rhizosphere soils in corn-soybean or PG plots, possibly due to the large root biomass/leaf loss to soils in perennial plots and residual soy/corn residue cover on soil in corn-soybean plots. Soil samples were divided for storage at 4 and $-20^{\circ} \mathrm{C}$.

Mean values of gravimetric soil moisture $\left(\mathrm{g} \mathrm{g}^{-1}\right)$ are shown in Fig. 1. Soil exchangeable $\mathrm{NO}_{3}^{-}-\mathrm{N}$ and $\mathrm{NH}_{4}^{+}-\mathrm{N}$ were determined for each of the soil samples by $\mathrm{KCl}$ extraction. Soil samples $(10.0 \mathrm{~g})$ were placed into $125 \mathrm{~mL}$ flasks and $100 \mathrm{~mL}$ of $2.0 \mathrm{M} \mathrm{KCl}$ was added to each flask. Flasks were stoppered and shaken for $1 \mathrm{~h}$ at 160 strokes per minute; solutions were allowed to settle and were then filtered through Whatman no. 42 filter paper (Whatman plc, ME, USA). Extractable $\mathrm{NO}_{3}^{-}-\mathrm{N}$ and $\mathrm{NH}_{4}^{+}-\mathrm{N}$ were determined colourmetrically with segmented flow analyses (AA3, SEAL Analytical, Wisconsin, USA) via a cadmium reduction (US Environmental Protection Agency, 1974) and a Berthelot reaction, respectively (Fig. 2). 
Table 1. Mean soil properties measured at the Elora Research Station.

\begin{tabular}{|c|c|c|c|c|c|c|c|c|c|c|}
\hline \multicolumn{2}{|c|}{$\begin{array}{c}\text { Cropping system/ } \\
\text { harvest }\end{array}$} & \multirow[t]{2}{*}{$\begin{array}{c}\mathrm{N} \text { rate } \\
\left(\mathrm{kg} \mathrm{ha}^{-1}\right)\end{array}$} & \multirow{2}{*}{$\begin{array}{l}\text { Bulk } \\
\text { density } 1 \\
\left(\mathrm{~g} \mathrm{~cm}^{-3}\right)\end{array}$} & \multicolumn{2}{|c|}{$\%$ organic carbon } & \multicolumn{2}{|c|}{$\%$ total carbon } & \multicolumn{3}{|c|}{$\begin{array}{c}\text { Yield } \\
\left(\text { dry tha }^{-1}\right)\end{array}$} \\
\hline & & & & $0-15 \mathrm{~cm}$ & $15-30 \mathrm{~cm}$ & $0-15 \mathrm{~cm}$ & $15-30 \mathrm{~cm}$ & 2011 & 2012 & Mean $^{2}$ \\
\hline Corn-soybean & Fall & 0 & $1.21 \mathrm{AB}$ & 1.88 & 1.06 & 2.22 & 1.86 & 5.341 & 2.912 & $\mathrm{E}$ \\
\hline Corn-soybean & Fall & 160 & $1.27 \mathrm{~A}$ & 1.79 & 1.47 & 2.25 & 2.11 & 9.92 & 7.882 & $\mathrm{BC}$ \\
\hline Miscanthus & Fall & 0 & $1.10 \mathrm{~B}$ & 2.06 & 1.44 & 2.27 & 1.72 & 17.62 & 12.77 & $\mathrm{~A}$ \\
\hline Miscanthus & Fall & 160 & $1.10 \mathrm{~B}$ & 2.13 & 1.63 & 2.36 & 1.84 & 17.43 & 18.32 & $\mathrm{~A}$ \\
\hline Miscanthus & Spring & 0 & $1.13 \mathrm{AB}$ & 2.09 & 1.53 & 2.31 & 1.69 & 12.66 & 13.38 & $\mathrm{AB}$ \\
\hline Miscanthus & Spring & 160 & $1.13 \mathrm{AB}$ & 2.24 & 1.42 & 2.47 & 1.89 & 14.33 & 14.56 & A \\
\hline Switchgrass & Fall & 0 & $1.11 \mathrm{~B}$ & 2.12 & 1.43 & 2.33 & 1.61 & 7.648 & 6.458 & $\mathrm{CD}$ \\
\hline Switchgrass & Fall & 160 & $1.09 \mathrm{~B}$ & 2.12 & 1.34 & 2.32 & 1.73 & 11.1 & 10.45 & $\mathrm{AB}$ \\
\hline Switchgrass & Spring & 0 & $1.11 \mathrm{~B}$ & 2.09 & 1.23 & 2.32 & 1.55 & 6.33 & 4.146 & $\mathrm{DE}$ \\
\hline Switchgrass & Spring & 160 & $1.21 \mathrm{AB}$ & 1.92 & 1.33 & 2.23 & 1.7 & 6.905 & 6.441 & $\mathrm{CD}$ \\
\hline
\end{tabular}

${ }^{1}$ Means of bulk density $(n=6)$ followed by the same letter within one column are not significantly different according to a post hoc Tukey's means comparison $(p<0.05)$; carbon measurements $(n=3)$ were not significantly different between treatments. ${ }^{2}$ Mean yields $(n=3)$ followed by the same letter are not significantly different according to a post hoc Tukey's means comparison $(p<0.05)$.

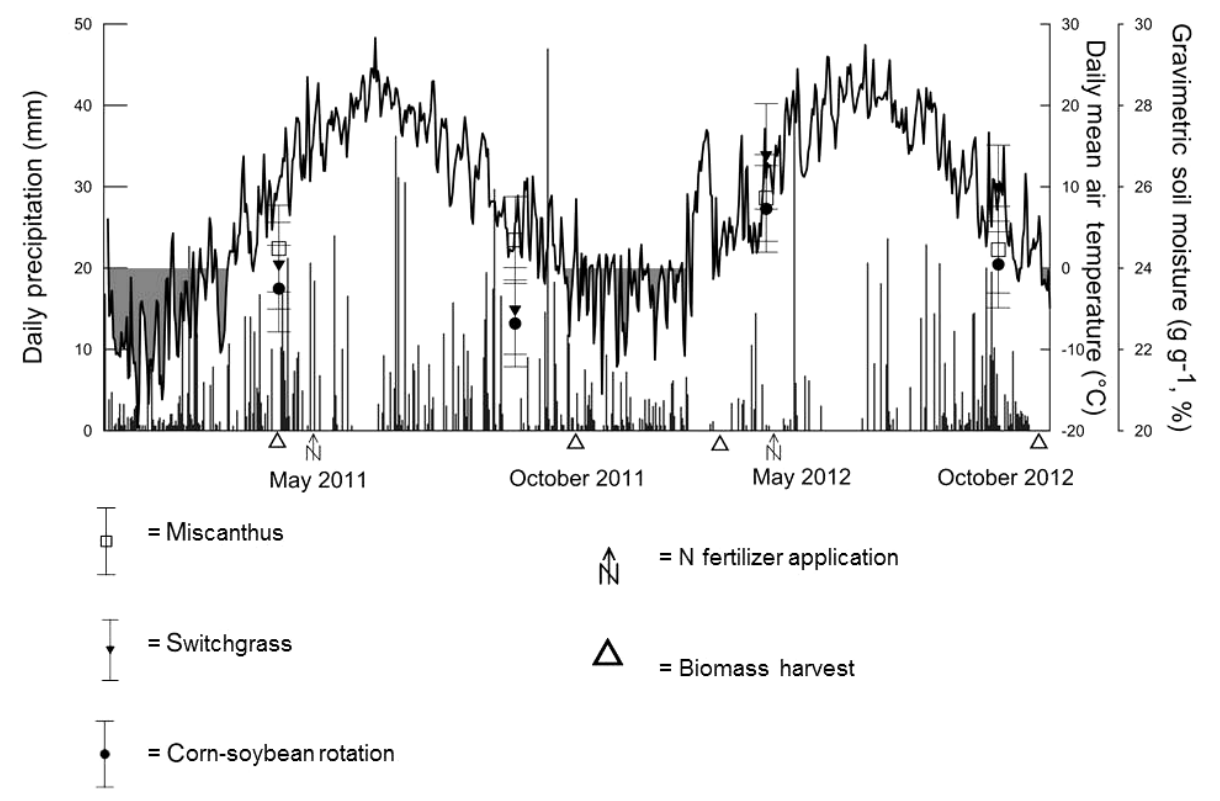

Figure 1. Mean daily air temperature $\left({ }^{\circ} \mathrm{C}\right)$ and daily precipitation $(\mathrm{mm})$ at the Elora Research Station from January 2011 to November 2012. Soil gravimetric $\mathrm{H}_{2} \mathrm{O}$ was measured on a per-sample basis and is shown as crop means $( \pm$ SE) for each sampling date (9 May 2011 , 30 October 2011, 2 May 2012, and 20 October 2012) ( $n=12$ in perennial grasses, $n=6$ in corn-soybean rotation).

\subsection{Soil DNA extraction}

Total DNA was extracted from field-moist soil sampled from each plot (three field replicates, $n=3$; total plots $n=30$ ). DNA was extracted in duplicate $(\sim 0.250 \mathrm{~g})$ within $48 \mathrm{~h}$ of sampling as per manufacturer's protocol using a PowerSoil DNA isolation kit (Mobio, Carlsbad, USA). Duplicate extracts were then pooled, separated into aliquots, and stored at $-80^{\circ} \mathrm{C}$ until use in downstream analyses.

\subsection{Quantification of total bacteria and functional genes}

Quantitative PCR (qPCR) assays were used to enumerate the total bacterial communities (16S rRNA gene) and communities of denitrifiers by targeting nitrite reductase (nirS) and nitrous oxide reductase (nos $Z$ ) genes, using primer pairs 338f/518r (16S rRNA; Fierer et al., 2005), Cd3af/R3Cd (nirS; Throbäck et al., 2004), and 1F/1R (nosZ; Henry et al., 2006).

For each gene target analyzed, duplicate replicates were run in parallel on an IQ5 thermocycler (Bio-Rad Laborato- 

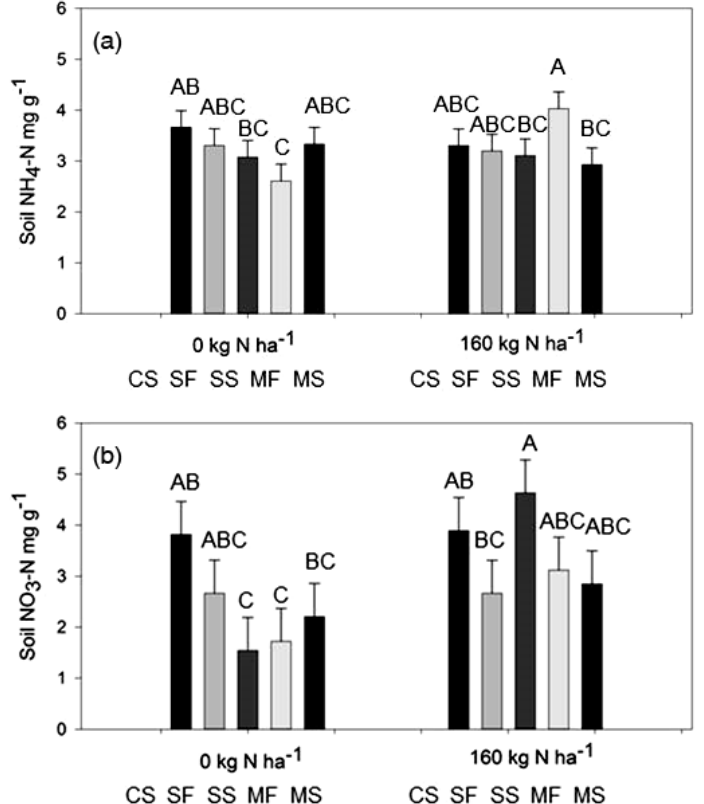

Figure 2. Mean soil $\mathrm{NH}_{4}-\mathrm{N}$ and $\mathrm{NO}_{3}-\mathrm{N}\left(\mathrm{mgg} \mathrm{g}^{-1}\right.$ dry soil $\left.\pm \mathrm{SE}\right)$ in annual and perennial biomass cropping systems under varied harvest and $\mathrm{N}$ management at the Elora Research Station. CS: corn-soybean; SF: fall-harvested switchgrass; SS: springharvested switchgrass; MF: fall-harvested miscanthus; and MS: spring-harvested miscanthus. Different letters within panels indicate significant differences according to a post hoc Tukey's test $(p<0.05)$.

ries, Hercules, CA, USA). qPCR reaction mixtures contained $12.5 \mu \mathrm{L}$ of $1 \times \mathrm{SYBR}$ Green Supermix, with each forward and reverse primer at a final concentration of $400 \mathrm{nM} ; 1 \mu \mathrm{L}$ of DNA template; and RNase/DNase-free water to a final volume of $25 \mu \mathrm{L}$. The SYBR Green Supermix contained $100 \mathrm{nM}$ $\mathrm{KCl}, 40 \mathrm{mM}$ Tris- $\mathrm{HCl}, 0.4 \mathrm{mM}$ dNTPs, 50 units $\mathrm{mL}^{-1}$ iTaq DNA polymerase, $6 \mathrm{mM} \mathrm{MgCl}$, SYBR Green $20 \mathrm{nM}$ fluorescein, and stabilizer (Bio-Rad Laboratories, Hercules, CA, USA).

Conditions for qPCR were an initiation step at $94^{\circ} \mathrm{C}$ for $2 \mathrm{~min}$, followed by 35 cycles of denaturing at $94^{\circ} \mathrm{C}$ for $30 \mathrm{~s}$, annealing at $57^{\circ} \mathrm{C}$ for $30 \mathrm{~s}\left(16 \mathrm{~S}\right.$ rRNA) or at $55^{\circ} \mathrm{C}$ for $60 \mathrm{~s}(\mathrm{nirS})$, followed by elongation at $72{ }^{\circ} \mathrm{C}$ for 30 (16S rRNA) or sixty (nirS) seconds. For nosZ, a touchdown protocol adapted from Henry et al. (2006) was used. Amplicon specificity was screened by running qPCR products on an ethidium bromide-stained gel $(1 \%$ agarose, $80 \mathrm{~V}$ for $20 \mathrm{~min}$ ) with a $100 \mathrm{bp}$ ladder, which resulted in clean bands for all gene targets. The 16S rRNA primers used are degenerate and have been cited as having $89-91 \%$ matching efficiency to all bacteria (Bergmark et al., 2012). The primers amplify one of two conserved regions in V3 of the SSU rRNA gene, resulting in a $\sim 200 \mathrm{bp}$ amplicon that is within small enough to amplify via qPCR methodology and amplifies for most bacterial taxa (Bakke et al., 2011).
Known template standards were made from cloned PCR products from pure culture genomic DNA (Clostridium thermocellum (16S), Pseudomonas aeruginosa (nirS), and Pseudomonas fluorescens (nosZ)) and transformed into Escherichia coli plasmids (TOPO TA cloning kit); plasmids were sequenced to confirm successful cloning and transformation of the target genes. Amplicon specificity was screened by running PCR products on an ethidium bromidestained gel ( $1 \%$ agarose, $80 \mathrm{~V}$ for $20 \mathrm{~min}$ ) with a $100 \mathrm{bp}$ ladder. PCR amplicons of cloned gene targets were sequenced by the Laboratory Services Department at the University of Guelph using an ABI Prism 3720 (Applied Biosystems, Foster City, CA, USA) to confirm target identity.

In all qPCR assays, all unknown samples were amplified in parallel with a triplicate serial dilution $\left(10^{1}-10^{8}\right.$ gene copies per reaction) of control plasmids. PCR assays were optimized to ensure efficiencies ranging from 93.0 to $106.4 \%$, with $R^{2}$ s ranging from 0.990 to 0.999 and standard curve slopes of -3.177 to -3.408 by testing serial dilutions of DNA extracts in order to minimize inhibition of amplification due to humic and fulvic contaminants. Duplicate notemplate controls were run for each qPCR assay, which gave null or negligible values. Melt curve analysis was used to confirm amplicon specificity. Normalization of DNA concentrations to grams of dry soil was used to give results on a biologically significant scale, which assumes similar DNA isolation efficiency across samples.

\subsection{Statistical analysis}

Analysis of variance was conducted in SAS 9.3 (Carlsbad, NC, USA) using a generalized linear mixed model (PROC GLIMMIX). The Shapiro-Wilks test was used to test for normality of data; studentized test for residuals confirmed the absence of outliers. The probability distributions of gene abundance data sets were log-normal or highly skewed and were analyzed using an overdispersed Poisson distribution for count data (Ver Hoef and Boveng, 2007). Bulk density, organic carbon, total carbon, nitrate, and ammonium data were log-transformed when required and fitted to the normal distribution.

Within each data set, sampling time was a repeated measure; independent and interactive fixed effects were associated with crop/crop rotation, nitrogen application rate, and harvest timing within perennial grasses, while field replicate and its associated interactions were random effects. The residual maximum likelihood method was employed to fit the model for all data sets. Several covariance structures were entertained before the variance components structure was chosen based on convergence and model fitting criteria. Individual treatment means within data sets were compared using a post hoc Tukey's test for all pairwise comparisons, with significance denoted at $p<0.05$.

Correlation analysis was used to assess nonparametric measures of statistical dependence between gene abundances 
and $\mathrm{H}_{2} \mathrm{O}, \mathrm{NO}_{3}^{-}-\mathrm{N}$ and $\mathrm{NH}_{4}^{+}-\mathrm{N}$ measured over time (Table $\mathrm{S} 1$ in the Supplement). Correlation analysis resulted in multiple significant correlations between variables; as such a principal component analysis was conducted in SAS (PROC FACTOR) on 120 samples using a VARIMAX rotation.

\section{Results}

\subsection{Environmental and soil conditions}

Environmental conditions varied during the periods prior to the four soil sampling dates (Fig. 1). Average air temperatures over the growing seasons (May-October) were 16.9 and $17.3^{\circ} \mathrm{C}$ in 2011 and 2012, respectively (Roy et al., 2014); average air temperatures in spring 2012 were warmer than normal and resulted in earlier emergence of PG crops compared to 2011. Cumulative monthly precipitation was above average prior to the May 2011 sampling date $(101 \mathrm{~mm}$ vs. $72 \mathrm{~mm}$ 30-year average in April 2011 and $113 \mathrm{~mm}$ vs. $82 \mathrm{~mm} \mathrm{30-}$ year average in May 2011) (Roy et al., 2014). In comparison, southern Ontario received very low cumulative precipitation in April 2012 (30 mm vs. $72 \mathrm{~mm} 30$-year average) and May 2012 (28 mm vs. $82 \mathrm{~mm}$ 30-year average) (Roy et al., 2014). Cumulative precipitation levels were lower in 2012 compared to 2011 from May to August (391 mm in 2011 vs. $186 \mathrm{~mm}$ in 2012); however, higher than normal precipitation levels occurred in October of $2011(129 \mathrm{~mm}$ vs. $77 \mathrm{~mm}$ 30 -year average) and both September $(106 \mathrm{~mm}$ vs. $77 \mathrm{~mm}$ 30 -year average) and October (127 mm vs. $77 \mathrm{~mm} \mathrm{30-year}$ average) of 2012 (Roy et al., 2014). Environmental conditions prior to soil sampling directly impact soil gravimetric content measured at the time of sampling (Fig. 1) and could also impact soil $\mathrm{N}$ and soil bacterial communities.

Soil physical and chemical properties were assessed in October 2010, after only 2 years of contrasting management since crop establishment in 2008. The corn-soybean rotation had higher soil bulk density than soils from both miscanthus and switchgrass plots harvested in the fall. No differences in total or organic soil carbon were detected between the corn-soybean rotation and the PG treatments at either the $0-15$ or $15-30 \mathrm{~cm}$ depth (Table 1). Soil $\mathrm{NH}_{4}-\mathrm{N}$ levels did not differ significantly between the corn-soybean rotation and the PG soils; however, $\mathrm{N}$ fertilization significantly increased $\mathrm{NH}_{4}-\mathrm{N}$ levels in soils from fall-harvested miscanthus plots $(p<0.05)$ (Fig. 2a). $\mathrm{N}$ fertilization also significantly increased $\mathrm{NO}_{3}-\mathrm{N}$ levels in spring-harvested switchgrass $(p<0.05)$ (Fig. 2b). From May to October 2011, soil $\mathrm{NH}_{4}-\mathrm{N}$ levels increased significantly and soil $\mathrm{NO}_{3}-\mathrm{N}$ levels decreased significantly in PG soils (data not shown); a similar trend was not observed in 2012 or for soils from the cornsoybean rotation in either year.

\subsection{Biomass yields}

Despite significant differences in precipitation between 2011 and 2012, biomass yields of miscanthus and switchgrass did not differ between years. In comparison, corn grain yields were higher in 2011 vs. 2012 (Table 1). Miscanthus produced higher yields (12.7-18.3 dry t ha ${ }^{-1}$ ) than either switchgrass or corn grain, regardless of $\mathrm{N}$ fertilization rate or harvest timing (Table 1). When harvested in the fall and $\mathrm{N}$ fertilized, switchgrass yields were not significantly lower (10.5-11.1 dry tha- $\left.{ }^{1}\right)$ than miscanthus yields. Switchgrass yields from unfertilized plots were not significantly different if harvested in the fall or spring; however, switchgrass yields from fertilized plots were significantly higher $(\sim 3-$ 4 dry tha ${ }^{-1}$ ) when harvested in the fall compared to yields obtained when switchgrass was windrowed over winter.

\subsection{Bacterial responses to annual and perennial crops and their management}

There was no statistically significant effect of $\mathrm{N}$ fertilization or any significant interactions between cropping system and sampling time on any of the targeted gene abundances. Therefore, we analyzed the impact of each biomass crop under specific harvest management on soil bacterial gene abundances (Table 2). Denitrifying (nosZ) gene copy abundances were affected by LUC; regardless of harvest or $\mathrm{N}$ management, mean nos $Z$ gene copies were higher in miscanthus plots than in the corn-soybean rotation, and nirS: nos $Z$ ratios were higher in the corn-soybean soils than in miscanthus or switchgrass soils $(p<0.05)$ (Table 2). Under fall harvesting management, biomass crop had no impact on total bacterial 16S rRNA gene copies or nirS gene copies. However, leaving miscanthus biomass standing over winter until spring resulted in significantly higher $16 \mathrm{~S}$ rRNA gene copies than observed in soils from fall-harvested biomass crops and significantly higher nirS gene copies than in fall-harvested switchgrass or the corn-soybean rotation (Table 2).

\subsection{Temporal changes in bacterial gene abundances}

Sampling date had a significant impact on gene abundances for all genes quantified (Fig. 3). Over both sampling years, 16S rRNA gene copies were significantly higher (5.2$5.4 \times 10^{9}$ gene copies $\mathrm{g}^{-1}$ dry soil) at fall (October) sampling dates compared to the $\sim 5.5-6.4 \times 10^{8}$ gene copies $\mathrm{g}^{-1}$ dry soil quantified at spring (May) sampling dates (Fig. 3). Populations of nirS and nos $Z$ denitrifiers represented $\sim 1.58$ and $0.26 \%$ on a gene-to-gene basis (nirS or nosZ to $16 \mathrm{~S}$ ) of the total bacterial community (data not shown) and did not follow similar trends with time of sampling (Fig. 3). The abundance of nirS gene copies was significantly higher in 2012 $\left(4.0 \times 10^{6}-1.6 \times 10^{7}\right.$ gene copies $\mathrm{g}^{-1}$ dry soil) compared to $2011\left(2.5-6.3 \times 10^{5}\right.$ gene copies $g^{-1}$ dry soil), with no significant differences between May and October sampling dates within each year (Fig. 3). The abundance of nosZ gene 
Table 2. Mean gene abundance responses to crop and harvest management, averaged over nitrogen application rate and time at the Elora Research Station.

\begin{tabular}{|c|c|c|c|c|c|}
\hline \multirow[t]{2}{*}{$\begin{array}{l}\text { Cropping } \\
\text { system }\end{array}$} & \multirow[t]{2}{*}{ Management } & \multirow{2}{*}{$\begin{array}{l}\text { Total soil } \\
\text { bacteria (gene } \\
\text { copy } \mathrm{g}^{-1} \text { soil)* } \\
16 \mathrm{~S}\end{array}$} & \multicolumn{2}{|c|}{$\begin{array}{l}\text { Soil denitrifying bacteria (gene } \\
\text { copy } \mathrm{g}^{-1} \text { soil) }\end{array}$} & \multirow[t]{2}{*}{$\begin{array}{l}\operatorname{nir} S: \operatorname{nos} Z \\
\left(\times 10^{-2}\right)\end{array}$} \\
\hline & & & $\operatorname{nirS}$ & nos $Z$ & \\
\hline Corn-soybean & Fall harvest & $1.35 \times 10^{9} \mathrm{~b}$ & $1.95 \times 10^{6} \mathrm{~b}$ & $2.63 \times 10^{5} \mathrm{~b}$ & 7.42 \\
\hline Miscanthus & Fall harvest & $1.38 \times 10^{9} \mathrm{~b}$ & $2.30 \times 10^{6} \mathrm{ab}$ & $4.47 \times 10^{5} \mathrm{a}$ & 5.15 \\
\hline Miscanthus & Spring harvest & $1.91 \times 10^{9} \mathrm{a}$ & $3.02 \times 10^{6} \mathrm{a}$ & $5.25 \times 10^{5} \mathrm{a}$ & 5.75 \\
\hline Switchgrass & Fall harvest & $1.41 \times 10^{9} \mathrm{~b}$ & $2.19 \times 10^{6} b$ & $3.55 \times 10^{5} \mathrm{ab}$ & 6.17 \\
\hline Switchgrass & Spring windrow & $1.48 \times 10^{9} \mathrm{ab}$ & $2.46 \times 10^{6} \mathrm{ab}$ & $3.98 \times 10^{5} \mathrm{ab}$ & 6.18 \\
\hline
\end{tabular}

* Means followed by the same letter within one column are not significantly different according to post hoc Tukey's means comparison at $p<0.05(n=24)$.

\section{Corn Switchgrass Miscanthus}

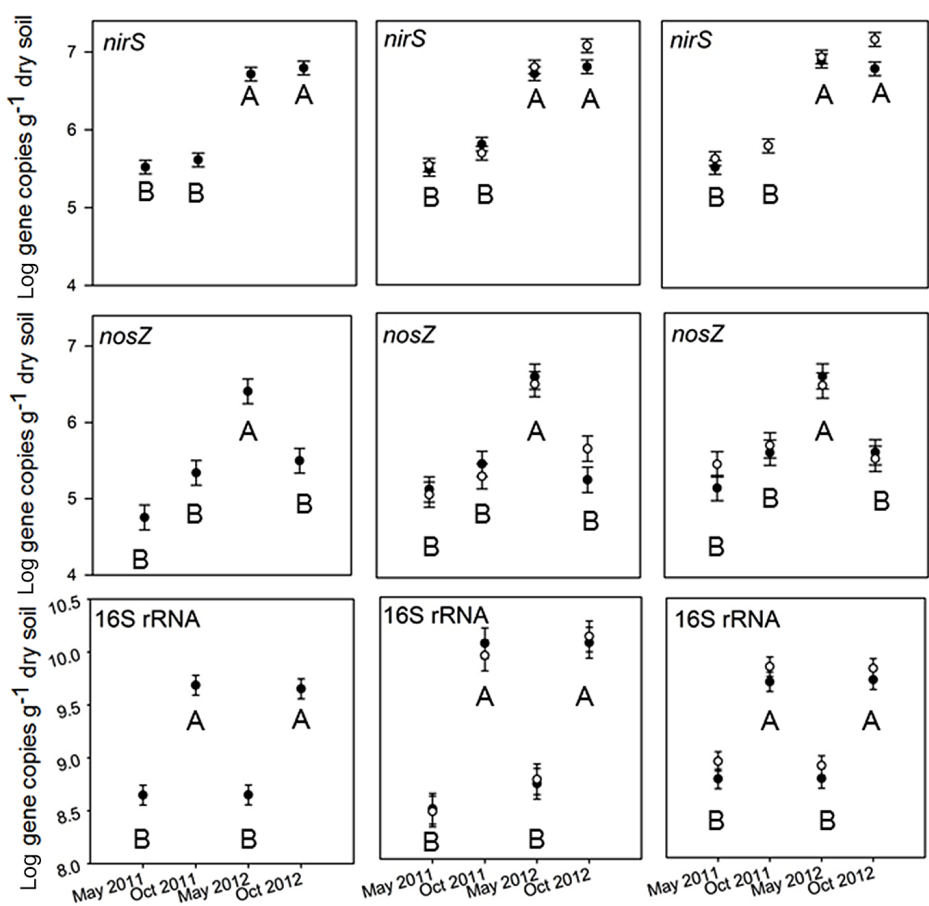

Figure 3. Mean log gene copies $\left(\mathrm{g}^{-1}\right.$ dry soil $\left.\pm \mathrm{SE}\right)$ in annual and perennial biomass cropping systems under varied harvest management at the Elora Research Station $(n=6)$ over time. Different letters within panels indicate significant differences according to a post hoc Tukey's test $(p<0.05)$.

copies was approximately $1.3-3.2 \times 10^{5}$ gene copies $\mathrm{g}^{-1}$ dry soil, but this increased significantly in May 2012 to approximately $3.2 \times 10^{6}$ gene copies $\mathrm{g}^{-1}$ dry soil and dropped back to previous levels by October 2012 (Fig. 3). Higher relative proportions of denitrifiers (nirS or nosZ to $16 \mathrm{~S}$ ) were observed at spring sampling dates, when total bacterial 16S rRNA gene abundances decreased in comparison to fall sampling dates (Fig. 3).

Two factors were selected in the principal components analysis, which accounted for $67.73 \%$ cumulative variance.
A scree plot was examined for breaks, and factors were retained for eigenvalues $\geq 1$. Soil $\mathrm{NH}_{4}-\mathrm{N}^{+}$, soil $\mathrm{NO}_{3}^{-}-\mathrm{N}$, nirS , and nosZ loaded on factor 1, which accounted for $43.89 \%$ variance, while soil gravimetric $\mathrm{H}_{2} \mathrm{O}$ and $16 \mathrm{~S}$ rRNA loaded on factor 2, which accounted for $23.84 \%$ variance (Fig. $4 \mathrm{a}$ and b). Differences in soil $\mathrm{NO}_{3}^{-}-\mathrm{N}$ and $\mathrm{NH}_{4}^{+}-\mathrm{N}$ were strongly related to differences in nirS and nos $Z$ gene abundances observed between May 2011 and May 2012 sampling dates (Figs. 3 and 4), while the size of the total bacterial com- 


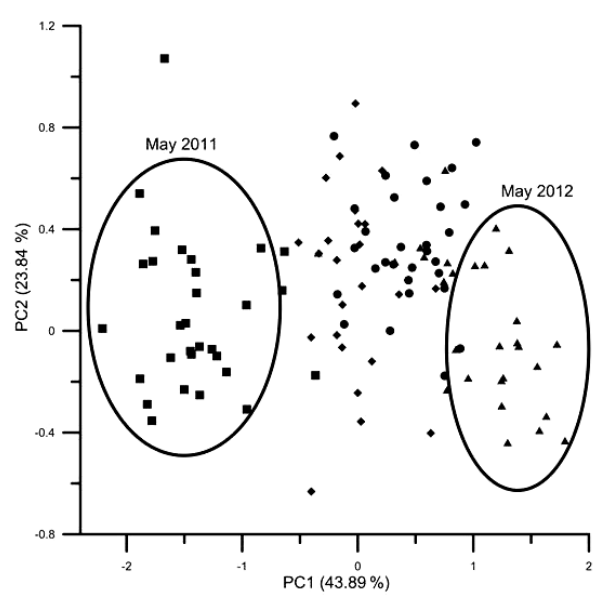

- $=$ May 2011
- $=$ October 2011
- = May 2012
- $=$ October 2012

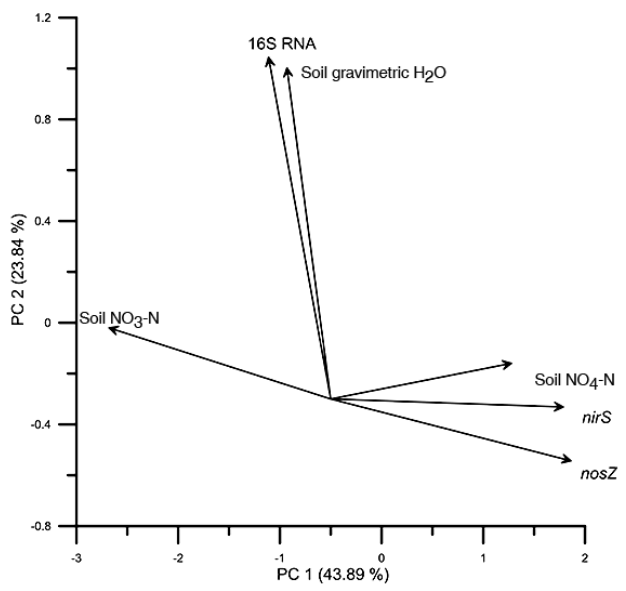

Figure 4. (a) Principal component analysis; factor 1 accounted for $43.89 \%$ variance and factor 2 accounted for $23.84 \%$ variance. (b) Loading plot for principal components of response variables (nirS, nosZ, and 16S rRNA gene copies, as well as soil $\mathrm{NO}_{3}-\mathrm{N}$, soil $\mathrm{NH}_{4}-\mathrm{N}$, and gravimetric soil $\mathrm{H}_{2} \mathrm{O}$ ).

munity (16S rRNA) was related to soil gravimetric moisture levels (Fig. 4).

\section{Discussion}

Denitrification is an important process contributing to the production and consumption of $\mathrm{N}_{2} \mathrm{O}$ in soils, and mitigation of greenhouse gases such as $\mathrm{N}_{2} \mathrm{O}$ is required to create sustainable biomass cropping systems (Miller et al., 2008; Schlesinger, 2013). Changes in the potential functional abilities of the soil microbial community may reflect changes in LUC or agricultural management and should be considered to assess the ecological impact of biomass crop production (Hedenec et al., 2014). Currently, few studies have assessed soil microbial community responses to PG biomass production systems (Hedenec et al., 2014; Liang et al., 2012; Mao et al., 2013, 2011; Orr et al., 2015). The highest potential to reduce greenhouse gas emissions from biomass cropping systems is to produce crops with high yields, such as PGs (Sanscartier et al., 2014), which offset the amount of land required for crop production (Kludze et al., 2013). However, if PG biomass production negatively affects soil health as indicated by changes in the potential functioning of microbial communities, large-scale LUC from annual to perennial biomass production may not be as sustainable as originally proposed. As such it is necessary to identify biomass cropping systems that not only result in large biomass yields but also ensure agroecosystem sustainability by maintaining or improving ecosystem services (Orr et al., 2015), such as soil $\mathrm{N}$ cycling.

\subsection{Biomass yields of annual and perennial crops}

Miscanthus and switchgrass biomass yields were within the typical range of values reported previously in Ontario (Kludze et al., 2013; REAP, 2008) and Europe (Christian et al., 2008; Himken et al., 1997), despite differences in temperature and precipitation between the two study years. Corn grain yields were within the lower range for reported Ontario yields (Munkholm et al., 2013), potentially due to wetter (2011) and drier (2012) field conditions than normal over the two growing seasons (Roy et al., 2014). Deen et al. (2011) showed increases in PG biomass yields between the second and third years after PG planting at our site, whereas we measured similar yields in 2011 and 2012, indicating the PGs may have reached maximum yield potential.

Nitrogen fertilization significantly increased corn grain yields and fall-harvested switchgrass biomass yields; however, no significant increases due to $\mathrm{N}$ fertilization were observed in miscanthus or spring-harvested switchgrass biomass yields. Potential yield increases from $\mathrm{N}$ fertilization in spring-harvested switchgrass may have been offset due to leaf loss over the winter season, as increases in switchgrass yields to $\mathrm{N}$ fertilization have been previously observed (Nikièma et al., 2011; Vogel et al., 2002). Similar to the present study, European and US field trials have also found no response of miscanthus yields to $\mathrm{N}$ (Lewandowski et al., 2000, 2003; Behnke et al., 2012; Christian et al., 2008), and PG yields were minimally impacted by differences in growing season conditions compared to corn grain yields (Table 1).

Despite significant differences in biomass yields between miscanthus and corn-soybean systems, there were no significant differences in either total or organic soil carbon between any of cropping systems assessed (Table 1). Sampling of soil carbon occurred only two years after PG planting; PGs are expected to be productive for $20+$ years, indicating future changes in soil carbon levels may occur. Additionally, Ontario-based land conversion modelling scenarios have estimated a soil carbon decrease of $2.5 \%$ upon miscanthus establishment (Sanscartier et al., 2014), which may have negated potential increases in soil organic carbon. However, high miscanthus yields most likely resulted in increases 
in above- and below-ground plant residue return to soils (Mutegi et al., 2010; Soil Quality National, 2006); therefore, our carbon measures may not have reflected short-term changes in labile carbon sources that had occurred. Regardless of management or climatic conditions, miscanthus consistently produced large yields, emphasizing its potential as a bioenergy crop suitable for production in variable Ontario conditions.

\subsection{Bacterial responses to annual and perennial crops and their management}

Some studies in biomass cropping systems have not observed differences in soil microbial responses between perennial and annual crop types (Mao et al., 2011), while others have measured significant differences in microbial abundance, diversity and community structure between these cropping types (Liang et al., 2012; Morales et al., 2010; Watrud et al., 2013). Currently, we observed significantly higher nos $Z$ gene copies in miscanthus soils compared to corn-soybean soils, illustrating a distinct effect of LUC from corn-soybean to miscanthus production on soil $\mathrm{N}$ cycling (Table 2).

Due to the large biomass produced by miscanthus compared to corn, a large amount of plant residues are returned to the soil; these residues provide surface cover, decrease soil bulk density, increase water retention, and regulate temperatures (Blanco-Canqui and Lal, 2009). Previous work at the Elora Research Station found an inverse correlation between field-scale $\mathrm{N}_{2} \mathrm{O}$ fluxes and nos $\mathrm{Z}$ transcript abundance in conventionally tilled corn plots with residues returned to soils (Németh et al., 2014), and increased nosZ activity after residue amendment has also been observed in lab studies (Henderson et al., 2010). High $\mathrm{C}: \mathrm{N}$ plant residues have been negatively correlated with cumulative $\mathrm{N}_{2} \mathrm{O}$ emissions (Huang, 2004) and may encourage complete reduction of $\mathrm{N}_{2} \mathrm{O}$ to $\mathrm{N}_{2}$ as soil available $\mathrm{NO}_{3}-\mathrm{N}$ is limiting, so bacterial populations with the ability to reduce $\mathrm{N}_{2} \mathrm{O}$ to $\mathrm{N}_{2}$ are favoured (Miller et al., 2008). Presently, the primers used for $n o s Z$ gene target amplification provided good coverage of $\gamma$-Proteobacteria (Henry et al., 2006), which are stimulated by surface-applied residues (Pascault et al., 2010). Increased residue return in miscanthus plots may have selected for bacterial populations harbouring enhanced catabolic capabilities, such as $\mathrm{N}_{2} \mathrm{O}$ reduction (Pascault et al., 2010). This implies that producing biomass crops with large yields may indirectly alter soil $\mathrm{N}$ cycling and potentially mitigate soil $\mathrm{N}_{2} \mathrm{O}$ emissions due to increased residue return influencing the soil microbial community. It is likely that differences in environmental conditions (e.g. temperature, $\mathrm{H}_{2} \mathrm{O}$ and $\mathrm{O}_{2}$ availability) and resource quality and availability between corn-soybean and miscanthus soils related to differences in microbial community structure (Cusack et al., 2011) and selected for different dominant taxa that filled different ecological niches (Stone et al., 2015).
$\mathrm{N}$ fertilization did not affect targeted gene abundances; however, studies in other cropping systems have found that $\mathrm{N}$ fertilization affected the size of denitrifying communities (Hallin et al., 2009), nitrifying communities (He et al., 2007), and proportions of nirS to nirK communities (ratio of nirS : nirK genes) (Hai et al., 2009). Elevated 16S rRNA and nirS gene copies were observed in soils from springharvested miscanthus and windrowed switchgrass (Table 2). Increased $\mathrm{N}$ return via senescent leaf loss in PG plots over winter contributes to the soil organic matter pool (Heaton et al., 2009) and may have contributed to elevated total (16S rRNA) bacterial populations in these soils, concomitantly increasing nirS abundances (Huang et al., 2011).

\subsection{Temporal changes in bacterial gene abundances}

Total soil bacterial communities (16S rRNA) followed a seasonal trend, with elevated 16S rRNA gene copies at fall (October) compared to spring (May) sampling dates, possibly due to an increase in the availability and diversity of resources for microbial metabolism and growth over the growing season (Habekost et al., 2008). Denitrifying abundances changed differently than the total bacterial community, suggesting denitrifiers were influenced by different proximal regulators than the total bacterial community (Figs. 3 and 4). Seasonal dynamics of N-cycling microbial communities have been previously characterized (Boyer et al., 2006; Németh et al., 2014; Wolsing and Priemé, 2004; Dandie et al., 2008; Bremer et al., 2007) and are tightly coupled with seasonal changes in labile $\mathrm{C}$ and $\mathrm{N}$ pools, temperature, and soil $\mathrm{H}_{2} \mathrm{O}$ (Butterbach-Bahl et al., 2013; Rasche et al., 2011), indicating that local edaphic drivers may often take precedence over crop-specific drivers (Mao et al., 2013).

\section{Conclusions}

Miscanthus consistently produced large yields and supported larger nosZ-bearing communities than the corn-soybean rotation, emphasizing its influence on soil $\mathrm{N}$ cycling and its potential to mitigate soil $\mathrm{N}_{2} \mathrm{O}$ emissions while being suitable for production in variable Ontario conditions. Additionally, miscanthus yields were not increased with $\mathrm{N}$ fertilization, indicating a lower $\mathrm{N}$ input requirement for biomass production compared to switchgrass. Higher 16S rRNA and nirS gene copies were associated with reduced yields in springharvested PGs, indicating that harvesting PGs in the spring may increase populations of denitrifiers capable of producing $\mathrm{N}_{2} \mathrm{O}$ emissions while simultaneously decreasing biomass yields. The size of both denitrifying ( irs and nos Z) and total bacterial (16S rRNA) communities changed over the sampling period; however, changes in denitrifying gene abundances did not parallel changes in the total soil bacterial community, indicating denitrifying communities were regulated differently than the total bacterial community. Future work measuring $\mathrm{N}_{2} \mathrm{O}$ emissions and denitrifier activity (mRNA) 
and community structure in these systems is required to link the effects of LUC on these communities directly with $\mathrm{N}_{2} \mathrm{O}$ fluxes.

\section{The Supplement related to this article is available online at doi:10.5194/soil-2-523-2016-supplement.}

Author contributions. Karen A. Thompson was the primary researcher and author on this study, conducting all field work, lab work, and manuscript preparation. Author Bill Deen is credited for the use of his OMAFRA-funded field plots for this research, and valuable advice on experimental design, statistical analyses, and manuscript focus. Author Kari E. Dunfield is credited for her invaluable mentorship on molecular analyses and troubleshooting on field sampling and sample preservation techniques, manuscript focus and preparation, and data interpretation.

Acknowledgements. Funding for this research was awarded through grants from the Natural Science and Engineering Research Council of Canada (NSERC), the Canada Research Chairs (CRC) Program, and the Ontario Ministry of Agriculture and Food and the Ministry of Rural Affairs (OMAF/MRA). Karen A. Thompson was also supported through an Ontario Graduate Scholarship (OGS) and an Ontario Graduate Fellowship (OGF). Special thanks to Henk Wichers (University of Guelph) for his expertise in managing the Alternate Renewable Fuels trial at the Elora Research Station.

Edited by: F. García-Orenes

Reviewed by: three anonymous referees

\section{References}

Adékambi, T., Drancourt, M., and Raoult, D.: The rpoB gene as a tool for clinical microbiologists, Trends Microbiol., 17, 37-45, doi:10.1016/j.tim.2008.09.008, 2009.

Attard, E., Recous, S., Chabbi, A., De Berranger, C., Guillaumaud, N., Labreuche, J., Philippot, L., Schmid, B., and Le Roux, X.: Soil environmental conditions rather than denitrifier abundance and diversity drive potential denitrification after changes in land uses, Global Change Biol., 17, 1975-1989, doi:10.1111/j.13652486.2010.02340.x, 2011.

Bakke, I., De Schryver, P., Boon, N., and Vadstein, O.: PCRbased community structure studies of Bacteria associated with eukaryotic organisms: A simple PCR strategy to avoid coamplification of eukaryotic DNA, J. Microbiol. Meth., 84, 349351, doi:10.1016/j.mimet.2010.12.015, 2011.

Bastian, F., Bouziri, L., Nicolardot, B., and Ranjard, L.: Impact of wheat straw decomposition on successional patterns of soil microbial community structure, Soil Biol. Biochem. 41, 262-275, doi:10.1016/j.soilbio.2008.10.024, 2009.

Behnke, G. D., David, M. B., and Voigt, T. B.: Greenhouse Gas Emissions, Nitrate Leaching, and Biomass Yields from Production of Miscanthus $\times$ giganteus in Illinois, USA, BioEnergy Res., 5, 801-813, doi:10.1007/s12155-012-9191-5, 2012.
Bergmark, L., Poulsen, P. H. B., Al-Soud, W. A., Norman, A., Hansen, L. H., and Sørensen, S. J.: Assessment of the specificity of Burkholderia and Pseudomonas qPCR assays for detection of these genera in soil using 454 pyrosequencing, FEMS Microbiol. Lett., 333, 77-84, doi:10.1111/j.1574-6968.2012.02601.x, 2012.

Bissett, A., Richardson, A. E., Baker, G., and Thrall, P. H.: Long-term land use effects on soil microbial community structure and function, Appl. Soil Ecol., 51, 66-78, doi:10.1016/j.apsoil.2011.08.010, 2011.

Blanco-Canqui, H. and Lal, R.: Crop Residue Removal Impacts on Soil Productivity and Environmental Quality, CRC. Crit. Rev. Plant Sci., 28, 139-163, doi:10.1080/07352680902776507, 2009.

Boyer, E. W., Alexander, R. B., Parton, W. J., Li, C., ButterbachBahl, K., Donner, S. D., Skaggs, R. W., and Del Grosso, S. J.: Modeling denitrification in terrestrial and aquatic ecosystems at regional scales, Ecol. Appl., 16, 2123-2142, 2006.

Braker, G. and Conrad, R.: Diversity, structure, and size of $\mathrm{N}_{2} \mathrm{O}$-producing microbial communities in soils-what matters for their functioning?, Adv. Appl. Microbiol., 75, 33-70, doi:10.1016/B978-0-12-387046-9.00002-5, 2011.

Bremer, C., Braker, G., Matthies, D., Reuter, A., Engels, C., and Conrad, R.: Impact of plant functional group, plant species, and sampling time on the composition of nirK-type denitrifier communities in soil, Appl. Environ. Microbiol., 73, 6876-6884, doi:10.1128/AEM.01536-07, 2007.

Butterbach-Bahl, K., Baggs, E. M., Dannenmann, M., Kiese, R., and Zechmeister-Boltenstern, S.: Nitrous oxide emissions from soils: how well do we understand the processes and their controls?, Philos. T. Roy. Soc. B, 368, 1-13, doi:10.1098/rstb.2013.0122, 2013.

Cantera, J. J. L. and Stein, L. Y.: Role of nitrite reductase in the ammonia-oxidizing pathway of Nitrosomonas europaea, Arch. Microbiol., 188, 349-354, doi:10.1007/s00203-007-02554, 2007.

Casciotti, K. L. and Ward, B. B.: Dissimilatory Nitrite Reductase Genes from Autotrophic Ammonia-Oxidizing Bacteria, Appl. Environ. Microbiol., 67, 2213-2221, doi:10.1128/AEM.67.5.2213-2221.2001, 2001.

Case, R. J., Boucher, Y., Dahllöf, I., Holmström, C., Doolittle, W. F., and Kjelleberg, S.: Use of 16S RNA and rpoB genes as molecular markers for microbial ecology studies, Appl. Environ. Microbiol., 73, 278-288, doi:10.1128/AEM.01177-06, 2007.

Christian, D. G., Riche, A. B., and Yates, N. E.: Growth, yield and mineral content of Miscanthus $\times$ giganteus grown as a biofuel for 14 successive harvests, Ind. Crops Prod., 28, 320-327, doi:10.1016/j.indcrop.2008.02.009, 2008.

Cuhel, J., Simek, M., Laughlin, R. J., Bru, D., Cheneby, D., Watson, C. J., Philippot, L., and Chèneby, D.: Insights into the effect of soil $\mathrm{pH}$ on $\mathrm{N}_{2} \mathrm{O}$ and $\mathrm{N}_{2}$ emissions and denitrifier community size and activity, Appl. Environ. Microbiol., 76, 1870-1878, doi:10.1128/AEM.02484-09, 2010.

Cusack, D. F., Silver, W. L., Torn, M. S., Burton, S. D., and Firestone, M. K.: Changes in microbial community characteristics and soil organic matter with nitrogen additions in two tropical forests, Ecology 92, 621-632, doi:10.1890/10-0459.1, 2011.

Dandie, C. E., Burton, D. L., Zebarth, B. J., Henderson, S. L., Trevors, J. T., and Goyer, C.: Changes in bacterial denitrifier community abundance over time in an agricultural field and their 
relationship with denitrification activity, Appl. Environ. Microbiol., 74, 5997-6005, doi:10.1128/AEM.00441-08, 2008.

Deen, B. B., Young, D., Rowsell, J., Tubeileh, A., Engbers, H., and Rosser, B.: A comparative study assessing variety and management effects on $\mathrm{C}_{4}$ perennial grasses in a northern climate, Asp. Appl. Biol., 112, 205-212, 2011.

Deslippe, J. R., Jamali, H., Jha, N., and Saggar, S.: Soil Biology \& Biochemistry Denitrifier community size, structure and activity along a gradient of pasture to riparian soils, Soil Biol. Biochem., 71, 48-60, doi:10.1016/j.soilbio.2014.01.007, 2014.

Dohleman, F. G., Heaton, E. A., Arundale, R. A., and Long, S. P.: Seasonal dynamics of above- and below-ground biomass and nitrogen partitioning in Miscanthus $\times$ giganteus and Panicum virgatum across three growing seasons, GCB Bioenergy, 4, 534544, doi:10.1111/j.1757-1707.2011.01153.x, 2012.

Enwall, K., Throbäck, I. N., Stenberg, M., Söderström, M., and Hallin, S.: Soil resources influence spatial patterns of denitrifying communities at scales compatible with land management, Appl. Environ. Microbiol., 76, 2243-2250, doi:10.1128/AEM.0219709, 2010.

Fierer, N., Jackson, J. A., Vilgalys, R., and Jackson, R. B.: Assessment of Soil Microbial Community Structure by Use of TaxonSpecific Quantitative PCR Assays, Appl. Environ. Microbiol., 71, 4117-4120, doi:10.1128/AEM.71.7.4117-4120.2005, 2005.

Foster, J. L., Guretzky, J. A., Huo, C., Kering, M. K., and Butler, T. J.: Effects of Row Spacing, Seeding Rate, and Planting Date on Establishment of Switchgrass, Crop Sci., 53, 309-314, doi:10.2135/cropsci2012.03.0171, 2013.

Gaudin, A. C. M., Janovicek, K., Deen, B., and Hooker, D. C.: Wheat improves nitrogen use efficiency of maize and soybeanbased cropping systems, Agr. Ecosyst. Environ., 210, 1-10, doi:10.1016/j.agee.2015.04.034, 2015.

Habekost, M., Eisenhauer, N., Scheu, S., Steinbeiss, S., Weigelt, A., and Gleixner, G.: Seasonal changes in the soil microbial community in a grassland plant diversity gradient four years after establishment, Soil Biol. Biochem., 40, 2588-2595, doi:10.1016/j.soilbio.2008.06.019, 2008.

Hai, B., Diallo, N. H., Sall, S., Haesler, F., Schauss, K., Bonzi, M., Assigbetse, K., Chotte, J.-L., Munch, J. C., and Schloter, M.: Quantification of key genes steering the microbial nitrogen cycle in the rhizosphere of sorghum cultivars in tropical agroecosystems, Appl. Environ. Microbiol., 75, 4993-5000, doi:10.1128/AEM.02917-08, 2009.

Hallin, S., Jones, C. M., Schloter, M., and Philippot, L.: Relationship between $\mathrm{N}$-cycling communities and ecosystem functioning in a 50-year-old fertilization experiment, ISME J., 3, 597-605, doi:10.1038/ismej.2008.128, 2009.

He, J.-Z., Shen, J.-P., Zhang, L.-M., Zhu, Y.-G., Zheng, Y.-M., Xu, M.-G., and Di, H.: Quantitative analyses of the abundance and composition of ammonia-oxidizing bacteria and ammoniaoxidizing archaea of a Chinese upland red soil under longterm fertilization practices, Environ. Microbiol., 9, 2364-2374, doi:10.1111/j.1462-2920.2007.01358.x, 2007.

Heaton, E. A., Dohleman, F. G., and Long, S. P.: Seasonal nitrogen dynamics of Miscanthus $\times$ giganteus and Panicum virgatum, GCB Bioenergy, 1, 297-307, doi:10.1111/j.17571707.2009.01022.x, 2009.

Hedenec, P., Novotny, D., Ustak, S., Cajthaml, T., Slejska, A., Simackova, H., Honzik, R., Kovarova, M., and Frouz, J.: The effect of native and introduced biofuel crops on the composition of soil biota communities, Biomass Bioenergy, 60, 137-146, doi:10.1016/j.biombioe.2013.11.021, 2014.

Henderson, S. L., Dandie, C. E., Patten, C. L., Zebarth, B. J., Burton, D. L., Trevors, J. T., and Goyer, C.: Changes in denitrifier abundance, denitrification gene mRNA levels, nitrous oxide emissions, and denitrification in anoxic soil microcosms amended with glucose and plant residues, Appl. Environ. Microbiol., 76, 2155-2164, doi:10.1128/AEM.02993-09, 2010.

Henry, S., Bru, D., Stres, B., Hallet, S., and Philippot, L.: Quantitative detection of the nosZ gene, encoding nitrous oxide reductase, and comparison of the abundances of $16 \mathrm{~S}$ rRNA, narG, nirK, and nosZ genes in soils, Appl. Environ. Microbiol., 72, 5181-5189, doi:10.1128/AEM.00231-06, 2006.

Himken, M., Lammel, J., Neukirchen, D., and Olfs, H.: Cultivation of Miscanthus under West European conditions?: Seasonal changes in dry matter production, nutrient uptake and remobilization, Plant Soil, 189, 117-126, 1997.

Huang, S., Chen, C., Yang, X., Wu, Q., and Zhang, R.: Distribution of typical denitrifying functional genes and diversity of the nirS-encoding bacterial community related to environmental characteristics of river sediments, Biogeosciences, 8, 30413051, doi:10.5194/bg-8-3041-2011, 2011.

Huang, Y.: Nitrous oxide emissions as influenced by amendment of plant residues with different $\mathrm{C}: \mathrm{N}$ ratios, Soil Biol. Biochem., 36, 973-981, doi:10.1016/j.soilbio.2004.02.009, 2004.

IPCC - Intergovernmental Panel on Climate Change: Climate Change 2007: The Physical Science Basis, in: Working Group I Contribution to the Fourth Assessment Report of the Inter- governmental Panel on Climate Change, edited by: Solomon, S., Qin, D., Manning, M., Chen, Z., Marquis, M., Averyt, K. B., Tignor, M., and Miller, H. L., Cambridge University Press, Cambridge, UK and New York, NY, USA, 996 pp., 2007.

Jayasundara, S., Wagner-Riddle, C., Dias, G., and Kariyapperuma, K. A.: Energy and greenhouse gas intensity of corn (Zea mays L.) production in Ontario: A regional assessment, Can. J. Soil Sci., 94, 77-95, doi:10.4141/cjss2013-044, 2014.

Kludze, H., Deen, B., Weersink, A., van Acker, R., Janovicek, K., and De Laporte, A.: Impact of land classification on potential warm season grass biomass production in Ontario, Canada, Can. J. Plant Sci., 93, 249-260, doi:10.4141/cjps2012-143, 2013.

Lewandowski, I., Clifton-brown, J. C., Scurlock, J. M. O., and Huisman, W.: Miscanthus?: European experience with a novel energy crop, Biomass Bioenergy, 19, 209-227, 2000.

Lewandowski, I., Andersson, B., Basch, G., Christian, D. G., Jørgensen, U., Jones, M. B., Riche, A. B., Schwarz, K. U., Tayebi, K., and Teixeira, F.: Environment and Harvest Time Affects the Combustion Qualities of of Miscanthus Genotypes, Agron. J., 95, 1274-1280, 2003.

Liang, C., Jesus, E. D. C., Duncan, D. S., Jackson, R. D., Tiedje, J. M., and Balser, T. C.: Soil microbial communities under model biofuel cropping systems in southern Wisconsin, USA: Impact of crop species and soil properties, Appl. Soil Ecol., 54, 24-31, doi:10.1016/j.apsoil.2011.11.015, 2012.

Mao, Y., Yannarell, A. C., and Mackie, R. I.: Changes in N-transforming archaea and bacteria in soil during the establishment of bioenergy crops, PLoS One, 6, 1-12, doi:10.1371/journal.pone.0024750, 2011. 
Mao, Y., Yannarell, A. C., Davis, S. C., and Mackie, R. I.: Impact of different bioenergy crops on N-cycling bacterial and archaeal communities in soil, Environ. Microbiol., 15, 928-942, doi:10.1111/j.1462-2920.2012.02844.x, 2013.

Maynard, D. G. and Curran, M. P.: Bulk Density Measurement in Forest Soil, in: ch. 66, Soil Sampling and methods of analysis, edited by: Carter, M. R. and Gregorich, E. G., Canadian Society of Soil Science, CRC Press, Boca Raton, FL, 863-869, 2007.

Miller, M. N., Zebarth, B. J., Dandie, C. E., Burton, D. L., Goyer, C., and Trevors, J. T.: Crop residue influence on denitrification, $\mathrm{N}_{2} \mathrm{O}$ emissions and denitrifier community abundance in soil, Soil Biol. Biochem., 40, 2553-2562, doi:10.1016/j.soilbio.2008.06.024, 2008.

Morales, S. E., Cosart, T., and Holben, W. E.: Bacterial gene abundances as indicators of greenhouse gas emission in soils, ISME J., 4, 799-808, doi:10.1038/ismej.2010.8, 2010.

Munkholm, L. J., Heck, R. J., and Deen, B.: Long-term rotation and tillage effects on soil structure and crop yield, Soil Till. Res., 127, 85-91, doi:10.1016/j.still.2012.02.007, 2013.

Mutegi, J. K., Munkholm, L. J., Petersen, B. M., Hansen, E. M., and Petersen, S. O.: Nitrous oxide emissions and controls as influenced by tillage and crop residue management strategy, Soil Biol. Biochem., 42, 1701-1711, doi:10.1016/j.soilbio.2010.06.004, 2010.

Németh, D. D., Wagner-Riddle, C., and Dunfield, K. E.: Abundance and gene expression in nitrifier and denitrifier communities associated with a field scale spring thaw $\mathrm{N}_{2} \mathrm{O}$ flux event, Soil Biol. Biochem., 73, 1-9, doi:10.1016/j.soilbio.2014.02.007, 2014.

Nikièma, P., Rothstein, D. E., Min, D.-H., and Kapp, C. J.: Nitrogen fertilization of switchgrass increases biomass yield and improves net greenhouse gas balance in northern Michigan, U.S.A., Biomass Bioenergy, 35, 4356-4367, doi:10.1016/j.biombioe.2011.08.006, 2011.

Nogales, B., Timmis, K. N., Nedwell, D. B., and Osborn, A. M.: Detection and Diversity of Expressed Denitrification Genes in Estuarine Sediments after Reverse Transcription-PCR Amplification from mRNA, Appl. Environ. Mcrobiol., 68, 5017-5025, doi:10.1128/AEM.68.10.5017-5025.2002, 2002.

Ontario Ministry of Energy, The Government of Ontario: Achieving Balance: Ontario's Long-Term Energy Plan, available at: http: //www.energy.gov.on.ca/ (last access: 8 January 2015), 2014.

Orr, M.-J., Gray, M. B., Applegate, B., Volenec, J. J., Brouder, S. M., and Turco, R. F.: Transition to second generation cellulosic biofuel production systems reveals limited negative impacts on the soil microbial community structure, Appl. Soil Ecol., 95, 6272, doi:10.1016/j.apsoil.2015.06.002, 2015.

Pascault, N., Nicolardot, B., Bastian, F., Thiébeau, P., Ranjard, L., and Maron, P.-A. A.: In situ dynamics and spatial heterogeneity of soil bacterial communities under different crop residue management, Microb. Ecol., 60, 291-303, doi:10.1007/s00248-0109648-z, 2010.

Périé, C. and Ouimet, R.: Organic carbon, organic matter and bulk density relationships in boreal forest soils, Can. J. Soil Sci., 88, 315-325, doi:10.4141/CJSS06008, 2008.

Petersen, D. G., Blazewicz, S. J., Firestone, M., Herman, D. J., Turetsky, M., and Waldrop, M.: Abundance of microbial genes associated with nitrogen cycling as indices of biogeochemical process rates across a vegetation gradient in Alaska, Environ. Mi- crobiol., 14, 993-1008, doi:10.1111/j.1462-2920.2011.02679.x, 2012.

Philippot, L.: Denitrifying genes in bacterial and Archaeal genomes, Biochim. Biophys. Acta, 1577, 355-376, 2002.

Philippot, L.: Use of functional genes to quantify denitrifiers in the environment, Biochem. Soc. Trans., 34, 101-103, doi:10.1042/BST0340101, 2006.

Philippot, L., Andert, J., Jones, C., Bru, D., and Hallin, S.: Importance of denitrifiers lacking the genes encoding the nitrous oxide reductase for $\mathrm{N}_{2} \mathrm{O}$ emissions from soil, Global Change Biol., 17, 1497-1504, doi:10.1111/j.1365-2486.2010.02334.x, 2011.

Rasche, F., Knapp, D., Kaiser, C., Koranda, M., Kitzler, B., Zechmeister-Boltenstern, S., Richter, A., and Sessitsch, A.: Seasonality and resource availability control bacterial and archaeal communities in soils of a temperate beech forest, ISME J., 5, 389-402, doi:10.1038/ismej.2010.138, 2011.

REAP - Resource Efficient Agricultural Production: ARF07 PROJECT Optimization of Switchgrass Management for Commercial Fuel Pellet Production, OMAFRA-Alternative Renew. Fuels Res. Dev. Fund., Canada, 2008.

Reeve, J. R., Schadt, C. W., Carpenter-boggs, L., Kang, S., Zhou, J., and Reganold, J. P.: Effects of soil type and farm management on soil ecological functional genes and microbial activities, ISME J., 4, 1099-1107, doi:10.1038/ismej.2010.42, 2010.

Roy, A. K., Wagner-Riddle, C., Deen, B., Lauzon, J., and Bruulsema, T.: Nitrogen application rate, timing and history effects on nitrous oxide emissions from corn (Zea mays L.), Can. J. Soil Sci., 94, 563-573, doi:10.4141/cjss2013-118, 2014.

Sanscartier, D., Deen, B., Dias, G., MacLean, H. L., Dadfar, H., McDonald, I., and Kludze, H.: Implications of land class and environmental factors on life cycle GHG emissions of Miscanthus as a bioenergy feedstock, GCB Bioenergy, 6, 401-413, doi:10.1111/gcbb.12062, 2014.

Schlesinger, W. H.: An estimate of the global sink for nitrous oxide in soils, Global Change Biol., 19, 2929-2931, doi:10.1111/gcb.12239, 2013.

Soil Quality National: Crop Residue Removal For Biomass Energy Production: Effects on Soils and Recommendations, Tech. Note 19, Soil Quality National Technology Development Team, USDA, Natural Resources Convservation Service, Greensboro, NC, USA, 1-7, 2006.

Sokhansanj, S., Mani, S., Turhollow, A., Kumar, A., Bransby, D., Laser, L. L., and Laser, M.: Large-scale production, harvest and logistics of switchgrass (Panicum virgatum L.) - current technology and envisioning a mature technology, Biofuels Bioprod. Bioprocess., 124-141, doi:10.1002/bbb.129, 2009.

Stone, M. M., Kan, J., and Plante, A. F.: Parent material and vegetation influence bacterial community structure and nitrogen functional genes along deep tropical soil profiles at the Luquillo Critical Zone Observatory, Soil Biol. Biochem., 80, 273-282, doi:10.1016/j.soilbio.2014.10.019, 2015.

Szukics, U., Abell, G. C. J., Hödl, V., Mitter, B., Sessitsch, A., Hackl, E., and Zechmeister-Boltenstern, S.: Nitrifiers and denitrifiers respond rapidly to changed moisture and increasing temperature in a pristine forest soil, FEMS Microbiol. Ecol., 72, 395406, doi:10.1111/j.1574-6941.2010.00853.x, 2010.

Throbäck, I. N., Enwall, K., Jarvis, A., and Hallin, S.: Reassessing PCR primers targeting nirS, nirK and nosZ genes for community 
surveys of denitrifying bacteria with DGGE, FEMS Microbiol. Ecol., 49, 401-417, doi:10.1016/j.femsec.2004.04.011, 2004.

Throbäck, I. N., Johansson, M., Rosenquist, M., Pell, M., Hansson, M., and Hallin, S.: Silver (Ag+) reduces denitrification and induces enrichment of novel nirK genotypes in soil, FEMS Microbiol. Lett., 270, 189-194, doi:10.1111/j.15746968.2007.00632.x, 2007.

US Environmental Protection Agency: Methods for chemical analysis of water and wastes, EPA-625-/6-74-003A, USEPA, Environmental Res. Center, Cincinnati, OH, 201-206, 1974.

Ver Hoef, J. M. and Boveng, P. L.: Quasi-Poisson vs. Negative Binomial Regression: How should we model overdispersed count data?, Ecology, 88, 2766-2772, 2007.

Vogel, K. P., Brejda, J. J., Walters, D. T., and Buxton, D. R.: Switchgrass biomass production in the midwest USA: Harvest and nitrogen management, Agronomy, 94, 413-420, 2002.

Vos, M., Quince, C., Pijl, A. S., De Hollander, M., and Kowalchuk, G. A.: A Comparison of rpoB and 16S rRNA as Markers in Pyrosequencing Studies of Bacterial Diversity, PLOS One, 7, 1-8, doi:10.1371/journal.pone.0030600, 2012.

Watrud, L. S., Reichman, J. R., Bollman, M. A., Smith, B. M., Lee, E. H., Jastrow, J. D., Casler, M. D., Collins, H. P., Fransen, S., Mitchell, R. B., Owens, V. N., Bean, B., Rooney, W. L., Tyler, D. D., and King, G. A.: Chemistry and Microbial Functional Diversity Differences in Biofuel Crop and Grassland Soils in Multiple Geographies, BioEnergy Res., 6, 601-619, doi:10.1007/s12155012-9279-y, 2013.
Wolsing, M. and Priemé, A.: Observation of high seasonal variation in community structure of denitrifying bacteria in arable soil receiving artificial fertilizer and cattle manure by determining TRFLP of nir gene fragments, FEMS Microbiol. Ecol., 48, 261271, doi:10.1016/j.femsec.2004.02.002, 2004.

Wu, L., Osmond, D. L., Graves, A. K., Burchell, M. R., and Duckworth, O. W.: Relationships Between Nitrogen Transformation Rates and Gene Abundance in a Riparian Buffer, Soil Environ. Manage., 50, 861-874, doi:10.1007/s00267-012-9929-z, 2012.

Yin, C., Fan, F., Song, A., Li, Z., Yu, W., and Liang, Y.: Different denitrification potential of aquic brown soil in Northeast China under inorganic and organic fertilization accompanied by distinct changes of nirS- and nirK-denitrifying bacterial community, Eur. J. Soil Biol., 65, 47-56, doi:10.1016/j.ejsobi.2014.09.003, 2014.

Zumft, W. G.: Cell biology and molecular basis of denitrification, Microbiol. Mol. Biol. Rev., 61, 533-616, 1997. 